\title{
Women and their role in labour Market: a Case Study conducted at North Eastern Coal Fields, Margherita, Assam
}

\author{
Upasona Sarmah \\ Asst. Professor, Department of Sociology Margherita College, Margherita 786181 Tinsukia, Assam
}

\begin{abstract}
The role of women in labour market is crucial in the sense that the rapid industrialization has created general employment opportunities for them from which most of them have been benefited. The North Eastern Coal Fields (NECF), Coal India Limited is one of the premier Central Government sector undertakings operating in Assam, which is playing a crucial role in accelerating the process of industrialisation as well as urbanization in Margherita Town at Tinsukia district of Assam. These two processes have a profound impact on the life of women employees working in this industry. Women from managerial position to the women engaged as workers in the collieries have witnessed a number of occupational hazards and professional challenges yet they are becoming economically independent. Though they are mostly employed at the lower levels, and in unskilled occupations, the process of urbanization enabled their daughters and most of them also to get exposed to education, information, health care, drudgery reduction and employment opportunities. They have to play multiple roles in the growing urbanized competitive world. The paper analyzes the occupational hazards and other professional difficulties faced by working women in the industry, and in the urban society with reference to the study area. The paper also focuses their multiple roles; the impact of urbanization on their family life, and their role in the labour market.
\end{abstract}

Keywords-Industrialization, Urbanization, Impact, Working Women, North Eastern Coal Fields, Discrimination.

\section{Introduction}

Industrial expansion, migration to urban areas, changing technology, western education and awareness of better standards of life etc enabled women, especially middle class, urban, educated women to take up work outside in significant numbers and this economic activity outside home helped them to experience financial and psychological independence to a certain expect. In North Eastern Coalfield there observes discrimination in the sense that there is the exclusion of females from managerial positions to a large extent. Out of 107 executives, who work at different levels, there are only three (4) female officers, out of which two (2) are medical officers and one (1) is HR manager and one is Account Officer. This exclusion of females affects the labour market, the equilibrium wage rate, the allocation of talent across working and managerial positions, the investment in education by individuals(males and females), and economic growth. This discrimination has a long lasting impact as it leads to lower equilibrium wages for female and male workers, and also reduces investment in human capital by all female and male workers. Have our labour market done enough to include women in their labour markets and take full advantage of the economic potential in them and are our labour markets as kind towards women as they are towards men? Are women satisfied with their opportunities and outcomes in the labour market? And are other demographic groups benefiting or hurt from the competition for jobs from women? These are the questions to be answered.

\section{OBJECTIVES OF THE STUDY}

2.1 To focus on the multiple roles working women plays in an urban industrial society.

2.2 To analyzes the occupational hazards and other professional difficulties faced by working women with reference to the study area.

2.3 To focus on the role of women, worked in collieries and their life-chances.

Some findings reveal that :

- There is no gainful employment in North Eastern Coal Fields (NECF) regarding women since year 2005. Only on compensatory ground some widows and family members have been appointed as dependent employment, which are given vocational training for one week and then engaged as surface female workers. Female employment has been reduced significantly.

- The working women in collieries are mostly illiterate. North Eastern Coal Fields (NECF) has no such schemes and programmes to make them literate and any schemes not been adopted neither by the organization nor by the trade unions yet. 
- $\quad$ There was once a women organization worked in NECF named WIPS (Women in Public sector) which was functional until 1994, but due to lack of women leaders, who could motivate others to take the initiative, the organization since then, become defunct.

- Women's increased participation in economic activity is regarded as an index of improvement in their social and economic status. But here, most of the woman workers are absorbed by the collieries, some of them work as 'Dependent Employee'(mostly engaged in unskilled and low level jobs) and almost $20 \%$ of the total workforce are absorbed by the informal/unorganized sector who worked under certain contractors, that does not provide job security, social security at all.

- These workers often settle in shanty and slum areas and no doubt able to find work but are spending their lives in insecure and polluted environment.

- Woman workers are having low participation in trade unions. There are no woman leaders perhaps. Even the ground level and surfaced level workers are not aware of what unions do.

- Very less woman are successful in attaining Managerial position. This does not mean that woman did not find their way to better paid, regular, secure jobs in the organized sector. Irrespective of the fact that they are educated, the sector of employment and the kind of work they performed the labour market discriminate them.

- Industrialization becomes successful only when it goes parallel with planned urbanization. This gap is observed in the nearby areas of collieries. Without infrastructure, such as public parks, sustainable urban drainage system, proper sanitation, greenways, it will lead to pollution and increasing slums which is observed in NEC Collieries.

Brockerhoff, M. (1999), has rightly pointed out that economic forces were such that cities became the ideal places to locate factories and their workers. Urban drift is the physical growth of industrial areas as a result of global change. Urbanization is closely linked to modernization, industrialization, and the sociological process of rationalization. Urbanization can describe a specific condition at a set of time, i.e. the proportion of total population or area in cities or towns, or the term can describe the increase of this proportion over time. So the term urbanization can represent the level of urban relative to overall population, or it can represent the rate at which the urban proportion is increasing. Urbanization occurs naturally from individual and corporate efforts to reduce time and expense in commuting and transportation while improving opportunities for jobs, education, housing, and transportation. Living in urban area permits individuals and families to take advantage of the opportunities of proximity, diversity, and marketplace competition. People move into urban areas to seek economic opportunities.

In the developed societies, modernization and urbanization are instrumental in improving the status of working women. Increased female participation in economic activity not merely liberated women from the tyranny of the 'household trap' but also enabled them to take decision on their fertility status and family size. But in our situation women are particularly vulnerable and they often disproportionately bear the burden of changes associated with urbanization. In the rural setup, they would work mostly at homes but the predominantly nuclear setup of the urban areas and sheer economies is forcing women to venture out. This is true in case of the women workers who work in different collieries. They have to face role conflict which has been observed in this industrial set up also. All these processes have no doubt brings positional changes into their status but changes at structural level hardly takes place. Their functional role in family has hardly changed.

2.4 Some observations of the study are :

- The women who work in collieries are mostly illiterate. When asked, why they do not join any adult schools, or whether they have the desire to make them literate most of them answered that they have to look after their children and husband after finishing their duties. So hardly there is a scope for adult schools and other opportunities. Most of them also informed that if they do that it will cause harm to their real responsibilities.-children, husband and home.

- These workers are not experienced in the 'politics of jobs', they do not tend to march forward for career advancement.

- Men and women both work in collieries as daily wage earners or monthly or piece rated wage earners. But Men are the bread winners, women's earning are seen as extra.

- Most of them have also lost their jobs due to child bearing and child rearing. Pregnancy compels them to leave their jobs on many grounds.

- There are very few role models for their support.

- There is hidden discrimination against these women workers.

- Most of them also often become the victim of domestic violence by their inmates.

The processes of modernization, and urbanization also had their impact on the employment of these workers. One of the most important features of such developed and technologically advanced society is that, 
there is high rate of mobility and social change. But in developing countries like India, such societies are changing but gradually and slowly because of the dead weight of traditionalism and socio-cultural barriers. The process of modernization has accelerated social change no doubt but it also gives birth to role conflict in case of these women to a large extent.

\section{Methodology}

In North Eastern Coal Fields (NECF), Coal India Limited, Margherita, a total number of 227 number of women works and maximum of them are engaged in colliery, who are mostly engaged in stone cleaning or as sale picking majdoor (a work which involves cleaning of coal from mud covering during and after excavation.) Numbers of daily rated workers are higher than the monthly rated women workers. Out of 227 women workers only 04 women are placed in the managerial position which includes two medical officers, one accounts officer and one HR manager. A pilot study was done to have an empirical evidence regarding structure of the interview schedule, phraseology and so on. These four women of managerial positions were purposively selected for the study and then went for purposive random sampling and 36 medical staff workers from NECF, (North Eastern Coalfields) hospital which comprises of doctors, nurses, female attendants, cleaner, clerks etc were also considered for the study. Some respondents were also considered from Personnel Department, Safety, Administration, Sales, Survey Department etc. of NECF. From the four collieries, we have randomly selected 45 respondents for interview. The total respondents taken for the study was 92. Focused group discussion was also done among the women who work mostly at unorganized sector, i.e. under different contractors.

IV. Table Shows Distribution Of Working Women In Various Levels (Work Positions) At Necf, Cil, Margherita

\begin{tabular}{|l|c|c|c|}
\hline \multicolumn{1}{|c|}{ Departments } & Monthly Rated & Daily Rated & Total \\
\hline $\begin{array}{l}\text { Colliery } \\
\text { (a) Tirap } \\
\text { (b) Ledo } \\
\text { (c) Borgolai } \\
\text { (d) Tipok }\end{array}$ & 15 & 80 & 95 \\
\hline Medical & & & \\
\hline Excavation and Mining & 02 (Executives) & 06 & 43 \\
\hline Civil & 35 & 07 & 07 \\
\hline Accounts & 00 & 03 & 03 \\
\hline Personnel & 00 & 02 & 07 \\
\hline Safety & 01 (Executive) & 04 & 02 \\
\hline Additional General Manager, Survey Office & 02 & 02 & 02 \\
\hline Ledo OCP (Open Cast Project) & 00 & 02 & 03 \\
\hline Senior Officer (Mining) & 01 & 00 & 01 \\
\hline Sales & 01 & 00 & 01 \\
\hline Land and Revenue & 01 & 01 & 03 \\
\hline Environment & 02 & 00 & 00 \\
\hline Control & 00 & 00 & 00 \\
\hline Administration & 00 & 02 & 02 \\
\hline ATO (Area Training Officer) & 00 & 03 & 11 \\
\hline Tipling & 08 & 01 & 02 \\
\hline Total & 01 & 23 & 30 \\
\hline
\end{tabular}

Source: Field Survey

(Executive level $=03$, Daily rated $=139$, Monthly rated $=85$ )

Total $=227$ working women in various level at NECF, CIL, Margherita

\section{Observations}

Female participation in the labour market is the most important change that has been accompanied with urbanization and modernization in Coal India limited, Margherita. Despande, S.and Despande, L. (1998) have said that the process is often defined as feminization in economic literature. Feminization internationally has resulted in a market increase in the participation rates of women which occur simultaneously with a decline in participation rates of men. Wherever the process was initiated, over time, women were absorbed in jobs which were performed earlier by men. Women were preferred by employers not necessarily for certain qualities that 
they possessed as workers but because female labour was flexible or disposable and cheap. Generally, women workers were less likely to be unionized and thereby low bargaining capacity. As a result they become victims of wage discrimination based on gender. They are paid lower wages than men, even though they are as educated as men in similar jobs. Women are forced to flock in certain occupations which are often termed "women's occupations". In the labour market, they experience higher levels of unemployment than men. And lastly, they are victims of pre-entry or human capital discrimination which does not permit women to have equal access to education with men. This inability to acquire education is held against them when they enter the labour market. They are left with limited options in terms of choice of jobs and are destined to have low paid employment. Despite the cumulative disadvantages women experienced as workers, faster growth of female employment to male employment implies basically two changes that are occurring in the labour market. On the demand side, employers definitely prefer cheaper and easily disposable female labour to dearer male labour. This clearly suggests that the society at large has accepted women as 'workers' or at least that society is less averse to working women now than in the past when they were expected to perform their traditional role of home-makers. Such a situation is largely found in this industry.

\subsection{The Evaluation :}

The women workers who work under different contractors at the collieries are mostly engaged in works such as stone picking,(removing the stones or other dust materials from coal) ,carrying coal for loading, excavation etc. It is a physically strain full job for them because they have to carry the coal from a long distance in order to unload it to the railway wagons. This physical strain results in ultimately poor health. After that, they have to again put a lot of efforts in collecting fire woods for their home consumption and for supplementing their family income. These women workers are mostly migrant workers, and not from the local and nearby areas. The contractors are supposed to hire machines for these works but they prefer to employ women workers for doing these activities. Most of the women also claimed that they started to do such works because the income from the male folk is inconsistent or insufficient or curtailed due to alcoholism among male members in the family and hence to supplement the family income. Other important cause for the choice of this occupation is that this is the traditional type of occupation done by the people living in the nearby areas. Physical effort is the only input and the reward is in the form of cash of Rs.160-180 per day. These women are not exposed to skilled or semi-skilled jobs and opportunities for acquiring such skills and employment in such areas are also not available here. A macro level analysis on their participation in the labour market reveals that the basic problems that affects the women's role and opportunities for employment spring from their helpless dependence, caused by lack of adequate employment opportunities, limited skills, illiteracy, restricted mobility, and lack of autonomous status.

Overall declining trend of women employment in NECF, is generally attributed to the adverse effects of productive labour laws for women such as maternity benefits, welfare amenities such as crèches, separate sanitary facilities, and the policy of equalizing wages.

While asking about their job satisfaction levels, to the two (2) medical officers, they replied that their salary package is quite satisfactory, but they have modest ambition, not ready to accept any transfer from their workplace and keep their family responsibilities on the top than their career advancement. In NECF, it is found that women are predominantly employed in consumption linked services and not in production linked industrial occupations. Female workers are concentrated in unskilled, low status low prestige, dead end jobs, such as midwives, health visitors, clerks, unskilled office workers, nurses, etc.

\section{The Professional Difficulties Faced By Working Women At Study Area}

- Operative level women who worked in collieries and those women who work under contractors are mostly illiterate which adversely affects their health. They dwells in the unhygienic colonies, barely have only one set of latrine amongst about twenty families. Lack of proper sanitation, poor drinking water facility is a serious threat towards their health and use of common latrine makes the whole region unhygienic and decease prone.

- There is no provision of crèche facility which is a major occupational hazard as expressed by most of them.

- There is a serious shortage of lady medical staff in the NECF hospital.

- There is no effective medical waste disposal system leading to severe unhygienic conditions surrounding the hospital.

- Special medical equipments such as health care monitoring system, retention anemia, ultrasound facilities etc. are not available. Various other modern medical equipments such as the mechanism of administering oxygen to the patient are totally outdated devoid of modern equipments.

- Women work in collieries and particularly in excavation work usually suffers from disease which is caused by the coal mine dust when exposed for a long period of their service career. 


\section{Conclusion}

It is worthwhile to note that women employment in NECF, Margherita, Assam has drastically downslides since 1994. In the period from 1994 until 2011, only 04 women have been employed in the NECF under the category of 'Dependent Employment.' The industry is itself not interested to give employment to women at higher positions. Women who joined coal industry as dependent employee are engaged here as surfaced female employee. Subtle form of sex discrimination is present in NECF, CIL.

Better networking, patronage, sponsorship and higher vision are required for the women to be successful in their career. Support structures such as reliable child care services, improved working conditions, particularly in medical and collieries, hostels for working women, crèche, day care centers, senior citizen hostels, social security measures are recourse to help these women in executing their occupational roles better who are still languishing in lower or middle level jobs at NECF, Margherita, Assam. The policy makers should remember that a society could only develop when; modernization and urbanization are used as tools to improve the status of working woman's both in organized and unorganized sector. Without job security, proper health, social security measures and proper recognition they would fail to cater the growing economic demand of the nation.

\section{References}

[1] Brockerhoff, M. Urban Growth in Developing Countries: A review of Projections and Predictions, Population and development Review, Vol 25. No4, PP 757-778, 1999.

[2] Brockerhoff, M. and Brennam, E The poverty of cities in Developing Regions, Populations and Development Review, Vol 24, No 1, pp 75-114, 1998

[3] Breese, G. Urbanisation in Newly Developing Countries, Prentice Hall, New Delhi., 1969.

[4] Despande, S.and Despande, L. Impact of Liberalisation of Labour Market in India: What Do Facts from NSSO's 50th Round Show, Economic and Political Weekly, Vol.33No 22, ppL21-L31, 1998.

[5] Davies Kingsley and Golden H.H. Urbanisation and development in pre-Industrial Areas, Economic Development and Cultural Change, Vol.3 no 1, 1954.

[6] Kundu, A. Theories of City Size Distribution and Indian Urban Structure - A Reappraisal, Economic and Political weekly, 18(3), 1983.

[7] Sarmah, U. Women workers: Their Occupational challenges and professional Hazards in North Eastern Coal Fields, Coal India Ltd., Margherita, Assam, Man and Life, ISRAA Bidisa, Vol 37(3-4), 2011. 